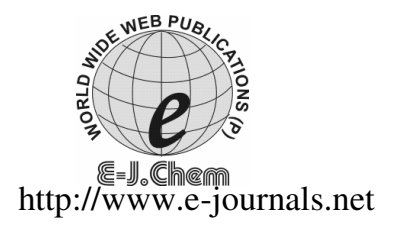

ISSN: 0973-4945; CODEN ECJHAO

E-Journal of Chemistry 2011, 8(1), 257-263

\title{
Monitoring of Trace Metal Pollution in Meenachil River at Kottayam, Kerala (India)
}

\author{
INDU.V.NAIR ${ }^{*}$, KAILASH SINGH ${ }^{\S}$, M. ARUMUGAM* and D.CLARSON \\ *Dept. of Earth Sciences, Annamalai University \\ Chidambaram, Tamilnadu, India \\ ${ }^{\S}$ Geologist, Geological Survey of India, Hyderabad, A.P, India \\ Agro Clinic \& Research Centre \\ Poovanthuruthu, Kottayam, Kerala, India \\ induvnair00@gmail.com
}

Received 11 February 2010; Revised 26 April 2010; Accepted 20 May 2010

\begin{abstract}
The water quality of the Meenachil river at Kottayam has been studied with reference to toxic trace metals during pre and post monsoon seasons for 10 stations during May 2009-September 2009. The metals analyzed include Zinc, Manganese, Iron, Lead, Copper and Cadmium. Among the metals studied, iron, lead and cadmium showed higher concentrations above the permissible limit for drinking water prescribed by Bureau of Indian Standards. Iron and lead showed higher concentration during post monsoon and the cadmium content was high during pre-monsoon. It was observed that the main causes of deterioration in water quality might be due to the discharge of domestic wastes, municipal wastes, terrestrial runoff from seepage sites, agricultural sites and also due to geological weathering process.
\end{abstract}

Keyword: Meenachil river, Water quality, Trace metals, Pre-monsoon, Post monsoon

\section{Introduction}

In recent years because of continuous growth in population, rapid industrialization and the accompanying technologies involving waste disposals, the rate of discharge of pollutants into the environment is far higher than the rates of their purification. Due to these reasons the preservation and maintenance of our natural water resources is a very difficult task. The quality of water resources is deteriorating day by day due to the continuous addition of undesirable chemicals ${ }^{1}$. On the other hand the demand for safe water is increasing continuously. Rivers play a major role in assimilating or carrying of industrial and municipal waste water, runoff from agricultural fields, roadways and street which are responsible for river pollution. Among various organic and inorganic water pollutants, metal ions are toxic, 
dangerous and harmful because of their tissue degradation in nature. Toxic metals are also bio-accumulative and relatively stable as well as carcinogenic and therefore require close monitoring ${ }^{2}$. River water is being used for domestic water supply in different parts of the world and therefore the analysis of toxic pollutants in river water has received great attention. Most of the rivers are deteriorating in quality gradually and the maintenance of the quality of river water will be a severe problem in the years to come.

According to surveys carried out by several researchers on some of the important rivers, it has been observed that in recent years most of these rivers are polluted. Houba $e t a l^{3}$ has reported the presence of cadmium, zinc, copper and lead in the Vesdre river, Belgium, while Latimer et $a l^{4}$ studied the metal pollution of the Pawtuxet river. Trace metal pollution in Umtata river, Nigeria was studied by Fatoki et al. ${ }^{5}$ and Suratman et al. ${ }^{6}$ studied distribution of selected trace metal in the Besut river, Malaysia. In India, various workers have determined ${ }^{7}$ the presence of toxic metals in Indian rivers. The physicochemical parameters and heavy metal contents of river Gomti, Lucknow ${ }^{8}$ and the metal pollution of Ganga river ${ }^{9}$ at Moradabad were analyzed by researchers. The water of river Gomti at Lucknow for certain heavy metals were analyzed and observed that it was polluted with copper, zinc and chromium. Jain et al. ${ }^{10}$ was studied the pollution potential of toxic metals in the Yamuan river at Delhi. Qualitative assessment ${ }^{11}$ of river Gomti at Lucknow emphasizing on the trace metals. ${ }^{12}$ Sinha et al. ${ }^{12}$ monitored the trace metal concentration in Gagan river water at Moradabad. The status of Meenachil river water quality at Kottayam town area with regard to the trace metal concentration during pre and post monsoon seasons of the year 2009 has been discussed in this paper.

\section{Study area}

Meenachil river which is one of the important river of Kottayam district in Kerala, emerges from Western ghats, flows through the taluks of Meenachil, Vaikom and Kottayam. It is also known as Kavanar splits into number of tributaries before ending into Vembanad Lake. This river has a total length of $78 \mathrm{~km}$ and has a catchment area of 1272 sq.km. The entire Meenachil watershed area geographically lies between $9^{0} 25^{\prime} \mathrm{N}$ to $9^{0} 55^{\prime}$ $\mathrm{N}$ latitude and $76^{\circ} 30^{\prime} \mathrm{E}$ to $77^{\circ} 00^{\prime} \mathrm{E}$ longitude. The general elevation of the entire river basin ranges from $77 \mathrm{~m}$ to $1156 \mathrm{~m}$ in the high lands and less than $2 \mathrm{~m}$ in the low lands. The river has a total annual yield of 2349 million cubic meters and an annual utilizable yield of 1110 million cubic meters. The river has 47 sub watersheds and 114 micro watersheds. The river has 38 tributaries including major and minor ones. The Meenachil river basin falls within the realm of tropical climate and high variations in relief from the west coast to the hilly region of the Western Ghats in the east and proximity to the sea influence the climatic parameters. The temperature of the area varies in between $24{ }^{\circ} \mathrm{C}$ and $32{ }^{\circ} \mathrm{C}$ throughout the year. The annual rainfall varies from less than $100 \mathrm{~cm}$ to more than $500 \mathrm{~cm}$ with an average of $300 \mathrm{~cm}$. The occasional rainfall is also received between the two seasons. The Meenachil river basin mainly comprises of precambrian metamorphic rocks which forms a hilly background. The major rock types are quartzite, charnokite, garnetiferous biotite gneiss and pink/gray granite. Towards the eastern parts of Vagamon, amphibiotite facies rocks are present. Quartz and pegmatite veins are traversing the country rock. Recent deposits cover the old rocks in some area. The major soil type prevalent in the area is well drained laterite soils. Also in some parts riverine alluvium soils and forest soils are also seen. Rubber trees are extensively cultivated in vast areas in the entire river basin. Besides rubber, other crops like spices, paddies etc. are also cultivated in the river basin area ${ }^{13}$. 


\section{Methodology}

In order to prepare the location map of the study area, Survey of India toposheet (No. 58 C/6 $\& \mathrm{C} / 10$ ) were used and the map was prepared with the help of Map info software. Global positioning system was used to find out the geographical location of the sampling spots. To carry out the present study of trace metal quality of Meenachil river at Kottayam town area, 10 sampling stations (Table 1) were chosen within the river basin. These sampling stations covered the upstream and downstream of the Meenachil river basin. Sampling was carried out during the pre-monsoon (May 2009) and post monsoon period (August 2009) of S-W monsoon. The sample bottles were soaked in $10 \%$ nitric acid for 24 hours and rinsed several times with double distilled water prior to use. The water samples were collected from midstream at $15 \mathrm{~cm}$ depth using a standard water sampler as prescribed by Bureau of Indian Standards ${ }^{14}$. After collection, the samples were kept in polythene bottles with the addition of $2 \mathrm{~mL}$ concentrated $\mathrm{HNO}_{3}$ for one litre to avoid precipitation. The samples thus preserved were stored at $4{ }^{\circ} \mathrm{C}$ in sampling kits and brought to the laboratory for trace metal analysis. Trace metals were extracted from the water samples through the digestion with nitric acid and the concentration was estimated using atomic absorption spectrophotometer (ELICO SL-176) ${ }^{15}$. All the chemical and reagents used were of analytical grade. Deionized water was used throughout the study. The data were statistically analyzed with the help of SPSS software (version 16.0). The test of significance for metal concentrations between pre and post monsoon seasons was done through Principal Component Analysis technique and between sampling locations was done through one way analysis of variance (ANOVA) at 95\% significance level.

Table 1. Description of sampling sites

\begin{tabular}{|c|c|c|c|c|}
\hline $\begin{array}{l}\text { Location } \\
\text { No. } \\
\end{array}$ & Location name & $\begin{array}{l}\text { Geographic } \\
\text { location }\end{array}$ & $\begin{array}{l}\text { Altitude } \\
\text { (Feet) }\end{array}$ & Activities noticed \\
\hline 1 & Nattasseri & $\begin{array}{c}9^{0} 36^{\prime} 4.8^{\prime \prime} \\
76^{0} 32 ' 12.7^{\prime},\end{array}$ & $-2.0 \mathrm{ft}$ & Domestic waste outlet \\
\hline 2 & Kumaranalloor & $\begin{array}{l}9^{0} 37^{\prime} 33.2^{\prime \prime}, \\
76^{0} 30^{\prime} 44.3^{\prime},\end{array}$ & $24 \mathrm{ft}$ & Domestic waste outlet \\
\hline 3 & Arpookara & $\begin{array}{l}9^{0} 35^{\prime} 53.2^{\prime}, \\
76^{0} 30^{\prime} 44.3^{\prime},\end{array}$ & $27 \mathrm{ft}$ & $\begin{array}{c}\text { Domestic and hotel waste } \\
\text { outlet }\end{array}$ \\
\hline 4 & Nagampadom & $\begin{array}{l}9^{0} 35^{\prime} 53.2^{\prime}, \\
76^{0} 31^{\prime} 41.2^{\prime},\end{array}$ & $34 \mathrm{ft}$ & $\begin{array}{c}\text { Sewage outlet from town, } \\
\text { hotels etc. }\end{array}$ \\
\hline 5 & Chungam & $\begin{array}{l}9^{0} 36^{\prime} 4.1^{\prime \prime} \\
76^{0} 31^{\prime} 3.3^{\prime}\end{array}$ & $13 \mathrm{ft}$ & Domestic waste disposal \\
\hline 6 & Aimanam & $\begin{array}{l}9^{0} 36^{\prime} 37.5^{\prime \prime} \\
76^{0} 29^{\prime} 37.5^{\prime}\end{array}$ & $25 \mathrm{ft}$ & Garbage waste disposal \\
\hline 7 & Thazhathangadi & $\begin{array}{l}9^{0} 35^{\prime} 44^{\prime}, \\
76^{0} 30^{\prime} 9.4^{\prime},\end{array}$ & $0 \mathrm{ft}$ & Domestic waste disposal \\
\hline 8 & Kodimatha & $\begin{array}{l}9^{0} 34^{\prime} 40^{\prime}, \\
76^{0} 31^{\prime} 8.9^{\prime},\end{array}$ & $17 \mathrm{ft}$ & $\begin{array}{l}\text { Sewage and hotel waste outlet } \\
\text { from town }\end{array}$ \\
\hline 9 & Illickal & $\begin{array}{l}9^{0} 35^{\prime} 19.1^{\prime}, \\
76^{0} 29^{\prime} 20.5^{\prime},\end{array}$ & $6 \mathrm{ft}$ & $\begin{array}{c}\text { Hotel and domestic waste } \\
\text { disposal }\end{array}$ \\
\hline 10 & Kumarakom & $\begin{array}{c}9^{0} 35^{\prime} 47^{\prime}, \\
76^{0} 25^{\prime} 50.8^{\prime}\end{array}$ & $8 \mathrm{ft}$ & $\begin{array}{l}\text { Sewage from town, domestic } \\
\text { waste, agricultural run off etc. }\end{array}$ \\
\hline
\end{tabular}




\section{Results and Discussion}

The concentration of trace metals obtained for Meenachil river water during pre and post monsoon seasons along 10 sampling stations are summarized in Table 2 and Table 3. The variation in trace metal concentration for pre and post monsoon seasons is graphically presented in Figure 1. It was apparently evident from the result that, the concentration of trace metals like $\mathrm{Fe}, \mathrm{Pb}$ and $\mathrm{Zn}$ were increasing during post monsoon and other metals were higher during pre monsoon period. The detailed discussion on the results are as follows:

Table 2. Trace metal content of Meenachil river at Kottayam during pre-monsoon

\begin{tabular}{ccccccc}
\hline $\begin{array}{c}\text { Sampling } \\
\text { location }\end{array}$ & $\begin{array}{c}\text { Copper } \\
\mathrm{mg} / \mathrm{L}\end{array}$ & $\begin{array}{c}\text { Iron } \\
\mathrm{mg} / \mathrm{L}\end{array}$ & $\begin{array}{c}\text { Manganese } \\
\mathrm{mg} / \mathrm{L}\end{array}$ & $\begin{array}{c}\text { Lead } \\
\mathrm{mg} / \mathrm{L}\end{array}$ & $\begin{array}{c}\text { Zinc } \\
\mathrm{mg} / \mathrm{L}\end{array}$ & $\begin{array}{c}\text { Cadmium } \\
\mathrm{mg} / \mathrm{L}\end{array}$ \\
\hline Nattasseri & 0.23 & 0.3 & 0.09 & 0.42 & $\mathrm{Nd}$ & 0.08 \\
Kumaranallur & 0.31 & 0.3 & 0.28 & $\mathrm{Nd}$ & $\mathrm{Nd}$ & 0.11 \\
Arpookara & 0.19 & 0.46 & 0.09 & $\mathrm{Nd}$ & $\mathrm{Nd}$ & 0.11 \\
Nagampadam & 0.08 & 0.3 & 0.3 & $\mathrm{Nd}$ & $\mathrm{Nd}$ & 0.09 \\
Chungam & 0.04 & 0.3 & 0.13 & $\mathrm{Nd}$ & $\mathrm{Nd}$ & 0.11 \\
Aimanam & 0.35 & 0.46 & 0.13 & $\mathrm{Nd}$ & $\mathrm{Nd}$ & 0.11 \\
Thazhathangadi & 0.04 & 0.38 & 0.13 & $\mathrm{Nd}$ & $\mathrm{Nd}$ & 0.11 \\
Kodimatha & 0.12 & 1.93 & 0.13 & $\mathrm{Nd}$ & $\mathrm{Nd}$ & 0.09 \\
Illickal & 0.35 & 0.38 & 0.13 & 0.42 & $\mathrm{Nd}$ & 0.11 \\
Kumarakom & 0.04 & 2.26 & 2.83 & 0.16 & $\mathrm{Nd}$ & 0.13 \\
\hline
\end{tabular}

Nd: Not detectable

Table 3. Trace metal content of Meenachil river at Kottayam during Post-monsoon

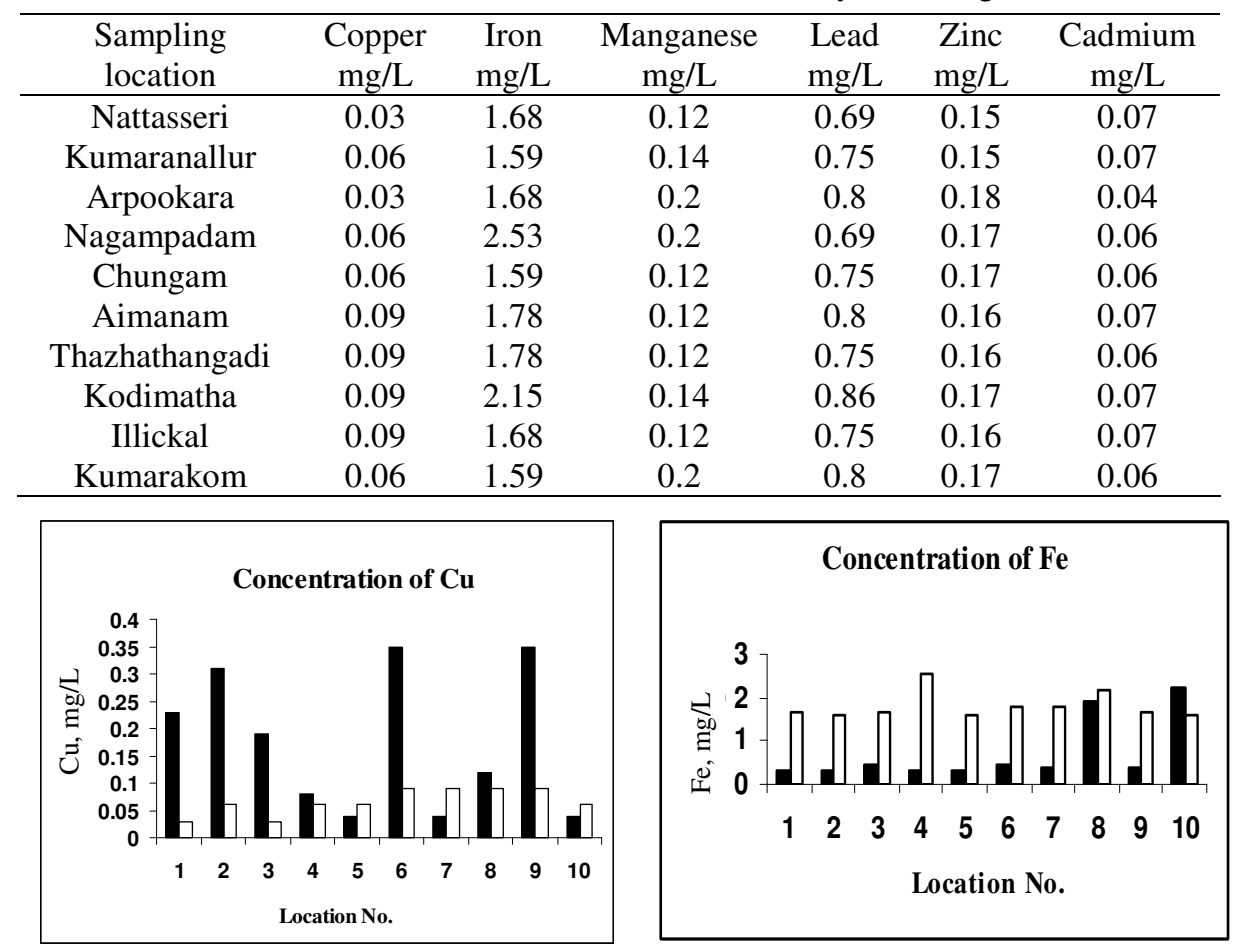



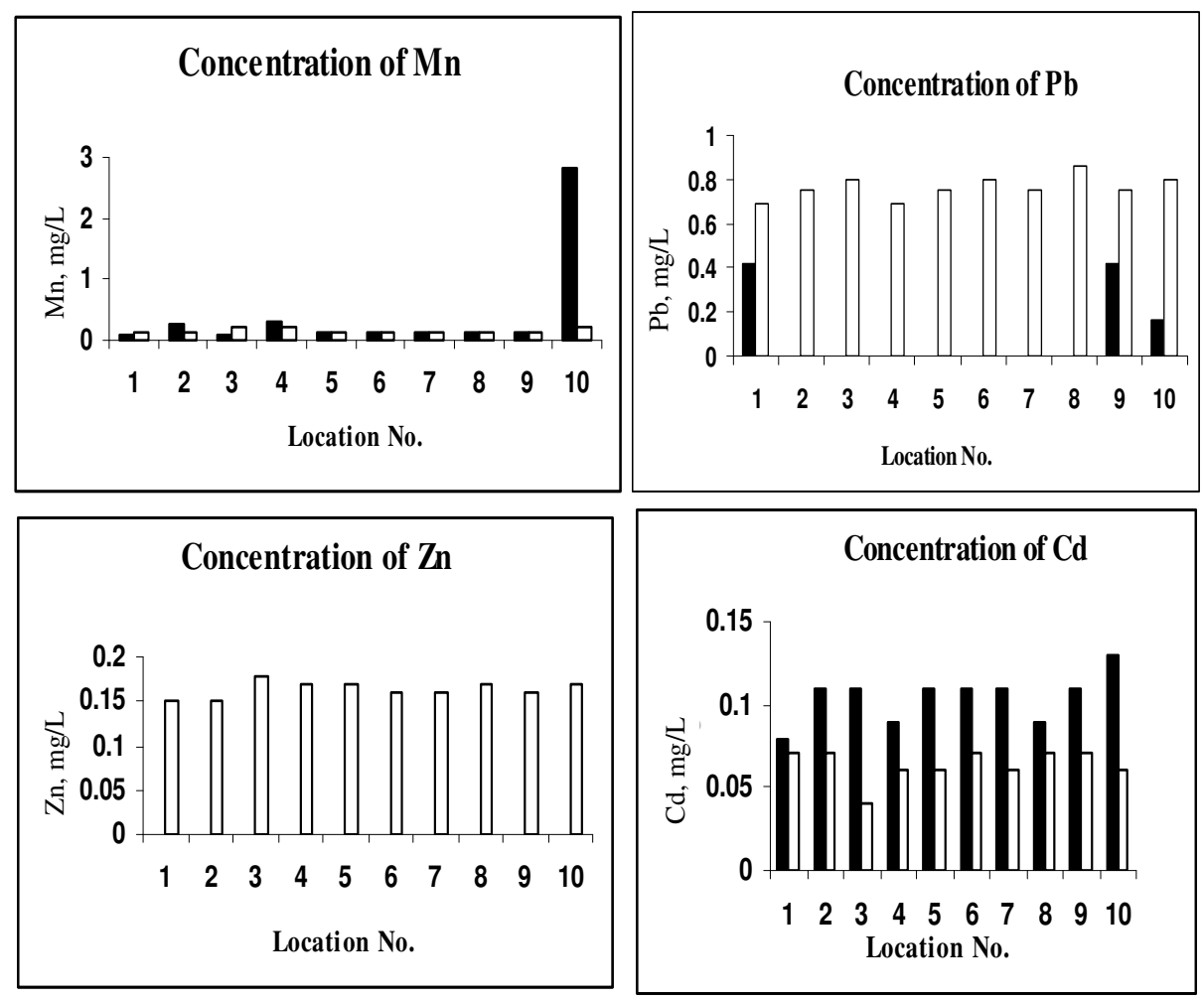

- Pre-Monsoon

Post Monsoon

Figure 1. Seasonal variation of trace metal in Meenachil river water

Present study revealed that, a general tendency of increasing the Fe content during post monsoon was observed throughout the entire study area. When compared with the BIS specification for drinking water, the iron content during post monsoon was above the permissible limit of $1.0 \mathrm{mg} / \mathrm{L}$, but it was below the limit during pre-monsoon. Since there is no major industrial activity in the study area, the major reason for the increase in $\mathrm{Fe}$ content might be due to the terrestrial runoff from the rocks present in the area. Charnockite groups of rocks which are rich in $\mathrm{Fe}$ content are the prevalent rock type in the basin ${ }^{16}$. They might have undergone weathering and erosion process during monsoon period. Another reason for the increase in Fe content might be due to the disposal of domestic wastes which is supported by the studies conducted by Neal et al ${ }^{17}$ and Bordalo et al. ${ }^{18}$ in which they found that domestic effluents act as an important source of trace metals. Excess of iron concentration in water causes staining of cloths and utensils. The water may also have a metallic taste and an offensive odor ${ }^{12}$.

The analytical data of $\mathrm{Pb}$ content showed that during post monsoon all the stations recorded higher values than the BIS permissible limit of $0.05 \mathrm{mg} / \mathrm{L}$. Water contamination due to $\mathrm{Pb}$ could be from sewage effluent discharge and also from seepage through waste sites in accordance with the studies done by Fatoki ${ }^{5}$. Water contaminated with lead may cause nuerological damage in foetus and also it is detrimental to pregnant women and young children ${ }^{19}$.

The analytical data of $\mathrm{Cd}$ was above the permissible limit of $0.01 \mathrm{mg} / \mathrm{L}$ for both the seasons. $\mathrm{Cd}$ is extremely toxic and the primary use of water high in $\mathrm{Cd}$ could cause adverse health effects such as renal disease and cancer ${ }^{20,21}$. The possible sources of contamination 
of $\mathrm{Cd}$ might be due to runoff from agricultural soil. The entire study area is covered by agricultural land where rock phosphate is used as phosphorous fertilizers in which $\mathrm{Cd}$ is a common impurity as supported by Stoeppler ${ }^{22}$ and Cherian ${ }^{23}$. According to Stoeppler and Cherian found that phosphorous fertilizers act as an important source of $\mathrm{Cd}$. During the entire study, the $\mathrm{Zn}, \mathrm{Cu}$ and Mn content were well within the BIS permissible values invariably among all the stations for both the seasons. Even though the metal concentrations were within the permissible limit, a minor increase of $\mathrm{Zn}$ level observed from pre-monsoon to post monsoon which might be due to agricultural runoff from the surrounding areas as evidenced by Tripathi et al. ${ }^{11}$. Also in the case of $\mathrm{Mn}$ a major increase observed at station 10 during pre-monsoon might be due to the addition of sewage and domestic wastes in bulk amount ${ }^{17}$.

The statistical analysis showed that the metal concentrations were significantly different $(<0.001)$ between the two seasons by KMO and Bartlett's test of sphericity. The $t$-test conducted to check the significance level of metal concentration between sampling locations showed that, during post monsoon all the metal concentrations were significantly different between sampling locations $(\mathrm{p}<0.05$ ) and during pre-monsoon, $\mathrm{Cu}, \mathrm{Fe}, \mathrm{Zn}$ and $\mathrm{Cd}$ satisfied the test of significance between the sampling locations.

\section{Conclusion}

In the present study, the Meenachil river water was analyzed for its trace metal concentrations. The data revealed that the concentrations of $\mathrm{Fe}, \mathrm{Pb}$ and $\mathrm{Cd}$ exceeded the permissible limit prescribed by BIS for drinking purpose. Since these metal ions are extremely toxic, the consumption of this river water may cause serious health. However, the assessment of trace metals for one particular season is not sufficiently representative for any assumption. The data evolved through this present study will provide some indicative trend for further future studies.

\section{Acknowledgment}

The authors are highly thankful to the staff of Department of Earth Sciences, Annamalai University, Chidambaram and Agro Clinic and Research Centre, Poovanthuruthu, Kottayam for all the support provided for the study.

\section{References}

1. L'vovich M I, Water Resources and Their Future; Litho Crafters Inc, Chelsea, Michigan, U.S.A, 1979.

2. Zuane J D, Hand Book of Dinking Water Quality; Van Nostrand Reinhold, New York, 1990, 47-51.

3. Houba C, Remade J, Dubois D and Thorez J, Wat Res., 1983, 17, 1281-1286.

4. Latimer J S, Carey C G, Hoffman E J and Quinn J G, Wat Resour Bull., 1988, 24(4), 791-800.

5. Fatoki O S, Lujiza N and Ogunfowokan A O, Water South Africa, 2002, 28(2), 183-189.

6. Suratman S, Hang H C, Shazili NAM and Mohd Tahir N, Bull Environ Contam Toxicol., 2009, 82, 16-19.

7. Pathak S P, Screening of microorganisms in Gomti river water under various environmental condition, Ph.D., Thesis, Lucknow University, Uttar Pradesh, India, 1991.

8. Sharma S D and Pande K S, Pollution Res., 1998, 17(2), 201-210.

9. Trivedi R K, Pollution and Bio-Monitoring of Indian Rivers; First Ed., Anish Publishing House, New Delhi. 2000, 1-29. 
10. Ali I and Jain C K, J Environ Hydrology, 2001, 9(12), 1-9.

11. Tripathi C P, Singh N K and Bhargava D S, J Instn Engrs India. Pt En 2006, 87(9), 27-34.

12. Sinha D K and Navneet Kumar, Indian J Environ Protect., 2006, 26(6), 516- 520.

13. Watershed Atlas, Kerala State Land Use board, Govt. of Kerala Publications, Kerala, 1996.

14. Bureau of Indian Standards, IS: 3025. Methods of sampling and test (Physical \& Chemical) for Water and Waste Water: Part I, Sampling; Bureau of Indian Standards, New Delhi. 1987.

15. APHA, Standard methods for examination of water and waste water $\left(19^{\text {th }}\right.$ Edn $), 1998$, American Public Health Association, Washington. D.C. 2005,U.S.A.

16. Geological Survey of India, District Resource Map (Geology and minerals) of Kottayam District, Kerala; Geological Survey of India, Kolkata. 2002,

17. Neal C, Jarvie H P, Whitton B A and Gemmell J, Sci Total Environ., 2000, 251/252: 153-172.

18. Bordalo A A, Nilsumranchit W and Chalermwat K, Wat Res., 2001, 35(15), 3635-3642.

19. Department of Water Affairs \& Forestry, Pretoria. DWAF, South African Water Quality Guidelines, Recreational Water use, 1996, Vol. 2,

20. Friberg L, Elinder C G, Kjellstroem T and Nordberg G F, Cadmium and health: A toxicological and epidemiological appraisal; Effects and response. CRC Press, Boca Raton, Florida, 1986, Vol. 11.

21. Kjellstroem T, Itai-itai disease. In: Cadmium and Health: A Toxicological and Epidemiological Appraisal; Effects and Response. CRC Press, Boca Raton, Florida, 1986, 11, 257 - 290.

22. Stoeppler M, Cadmium In: Merian E (Ed.,) Metals and their compounds in the Environment Occurrence; Analyses and Biological Relevance, VCH, New York, 1991, 803 - 851.

23. Cherian M G and Goyer A A, Comments Toxicol., 1989, 3, 191-206. 


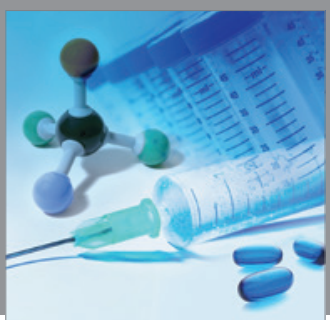

International Journal of

Medicinal Chemistry

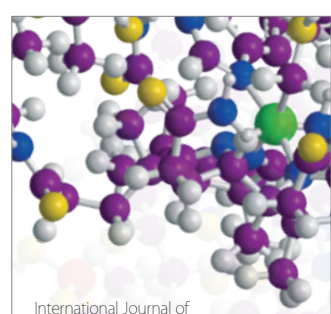

Carbohydrate Chemistry

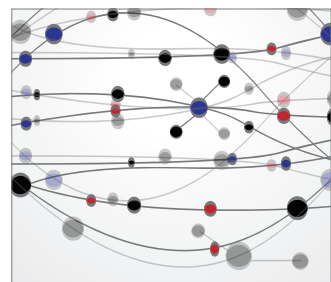

The Scientific World Journal
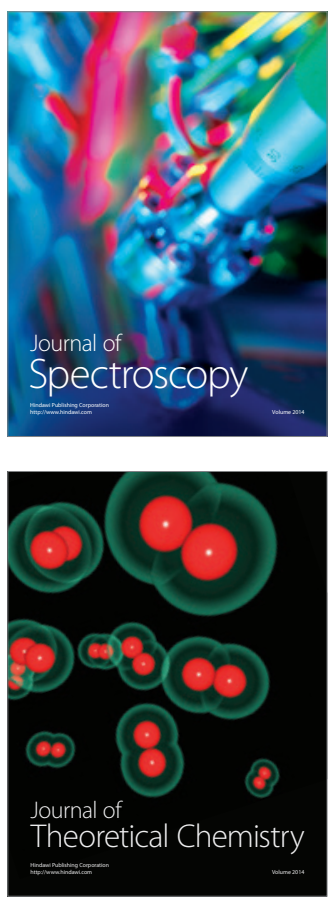
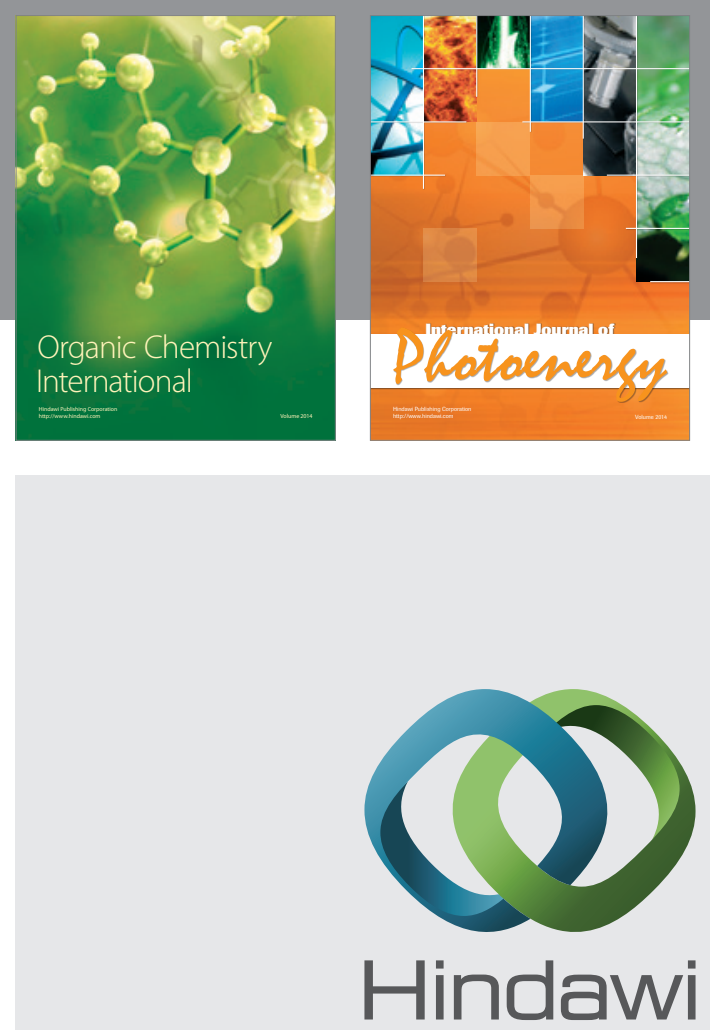

Submit your manuscripts at

http://www.hindawi.com
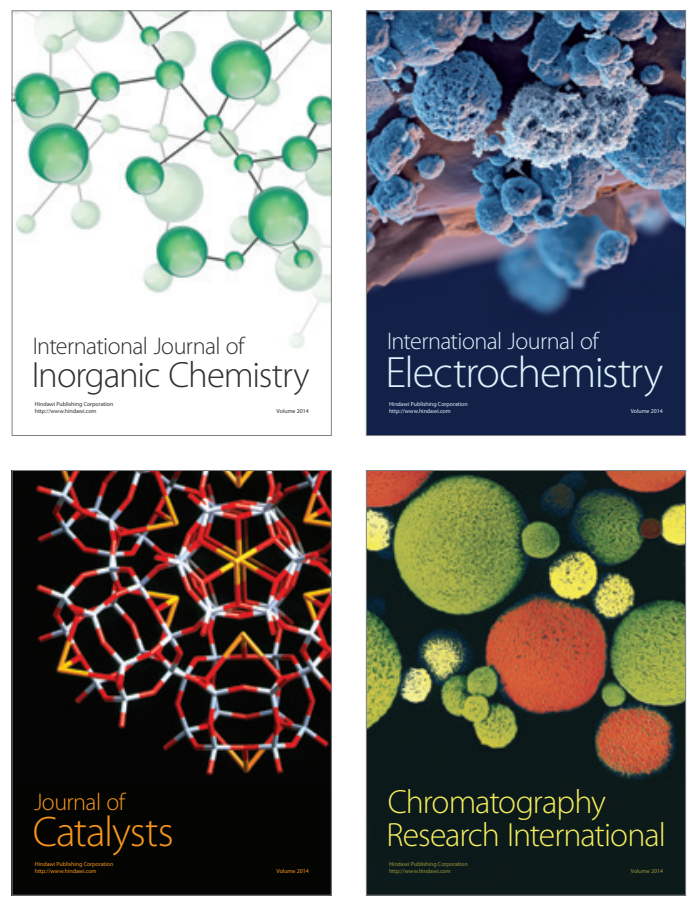
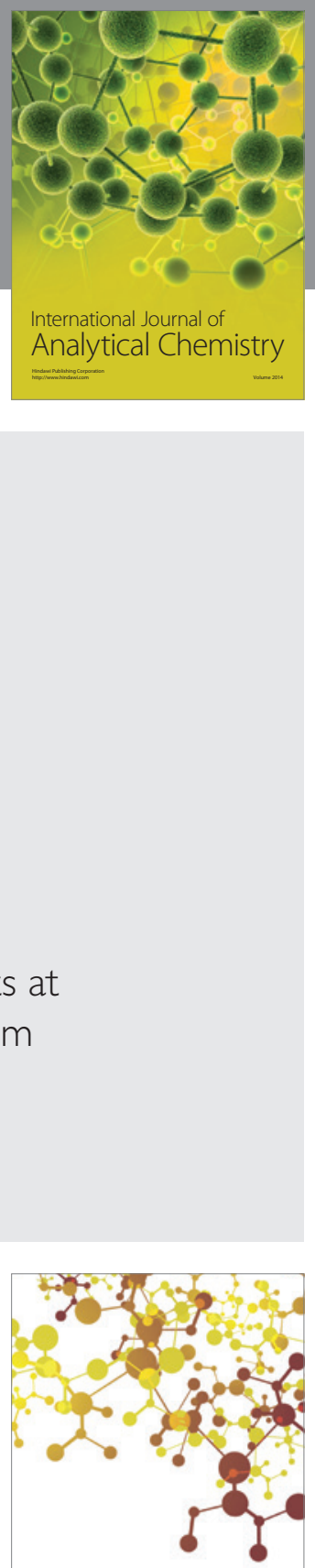

Journal of

Applied Chemistry
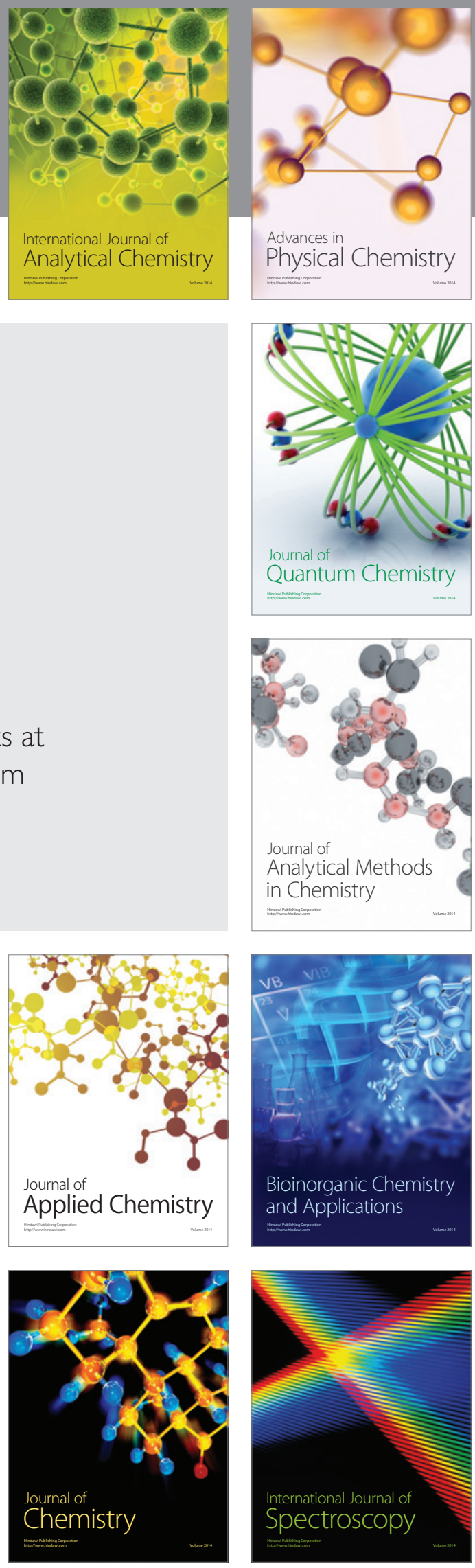